\title{
THE LOWER REACHES OF THE DAUGAVA IN THE BRONZE AND THE EARLIEST IRON AGE (1800-500 TO THE 1ST CENTURY BC)
}

\author{
ANDREJS VASKS ${ }^{*}$
}

University of Latvia, Institute of Latvian History, Kalpaka bulvāris 4, LV-1050, Riga, Latvia

Keywords

Lower Daugava, Bronze and Earliest Iron Age, Reznes cemetery, bronze processing, exchange, society

\begin{abstract}
The lower reaches of the Daugava in the Mesolithic and Neolithic were sparsely populated until the second half of the Early Bronze Age (1800-1100 BC). The situation began to change from the 14th century $\mathrm{BC}$, when the process of Neolithisation was over, and the local communities switched completely to animal husbandry and agriculture. In terms of social and economic relations, the area reached its highest level of development in the Late Bronze Age (1100-500 BC), which continued, albeit with a downward trend, in the Earliest Iron Age (500-1 BC). The article discusses the conditions that promoted the economic prosperity and social development of societies in the lower reaches of the Daugava in the direction of differentiation. The most important condition for this development was the involvement of lower Daugava societies in the long-distance exchange network between Scandinavia and the Volga-Kama region, where the main object of exchange was bronze, and the related focus on the processing of it in downstream centres. These metal products, weapons and jewellery, and their limited availability, were elements in the demonstration of social prestige. With the spread of local iron metallurgy in Eastern Europe and Scandinavia, the long-distance exchange of bronze lost its former importance. Consequently, the main bronze processing centres in the lower reaches of the Daugava also declined, and a collapse occurred in the existing socio-economic system.
\end{abstract}

\section{Introduction}

The lower reaches of the Daugava, from the Ogre tributary to the Gulf of Riga, are bounded to the south by a marshy area (Babìte Lagoon, Maztīrelis, Cena, Olaine Marshes), but to the north by the former Litorina Sea lagoon lakes (Lake Jugla, Kīšezers, Baltezers) and a strip of marshy lowlands of rivers. Judging by the relatively large number of archaeological sites and stray finds, the lower reaches of the Daugava were already attractive in prehistoric Latvia, and played a significant role in the life of Latvia's ancient societies. In the Bronze Age and the Earliest Iron Age, sometimes referred to as the Early Metal Period, the area can be considered an advanced model territory, which reflects the social, economic and ideological changes in east Baltic societies over a period of 2,000 years.
Researchers looked at the archaeology of the lower reaches of the Daugava as early as the 1930s, and in the 1970s to the 1990s, in connection with the oldest population of Riga and its surroundings (Šturms 1936; Vankina 1975; Zagorska 1998; Loze 1998; Graudonis 1998). The Daugava has played an important role as a waterway in maintaining connections between near and distant regions since the Stone Age. At the end of the Palaeolithic, reindeer hunters moved from the southeast along the banks of the river, reaching its lower reaches (Zagorska 2012, Fig. 21). The seasonal settlement of these first inhabitants has been extensively studied in Salaspils Laukskola, but traces of similar settlements are also known in several other places in the lower reaches of the Daugava (Elkšņi in Ikšķile, Lipši near Salaspils, Nariṇi in Tome, Čabas in Ciemupe). The only

* E-mail: andrejs.vasks@lu.lv 


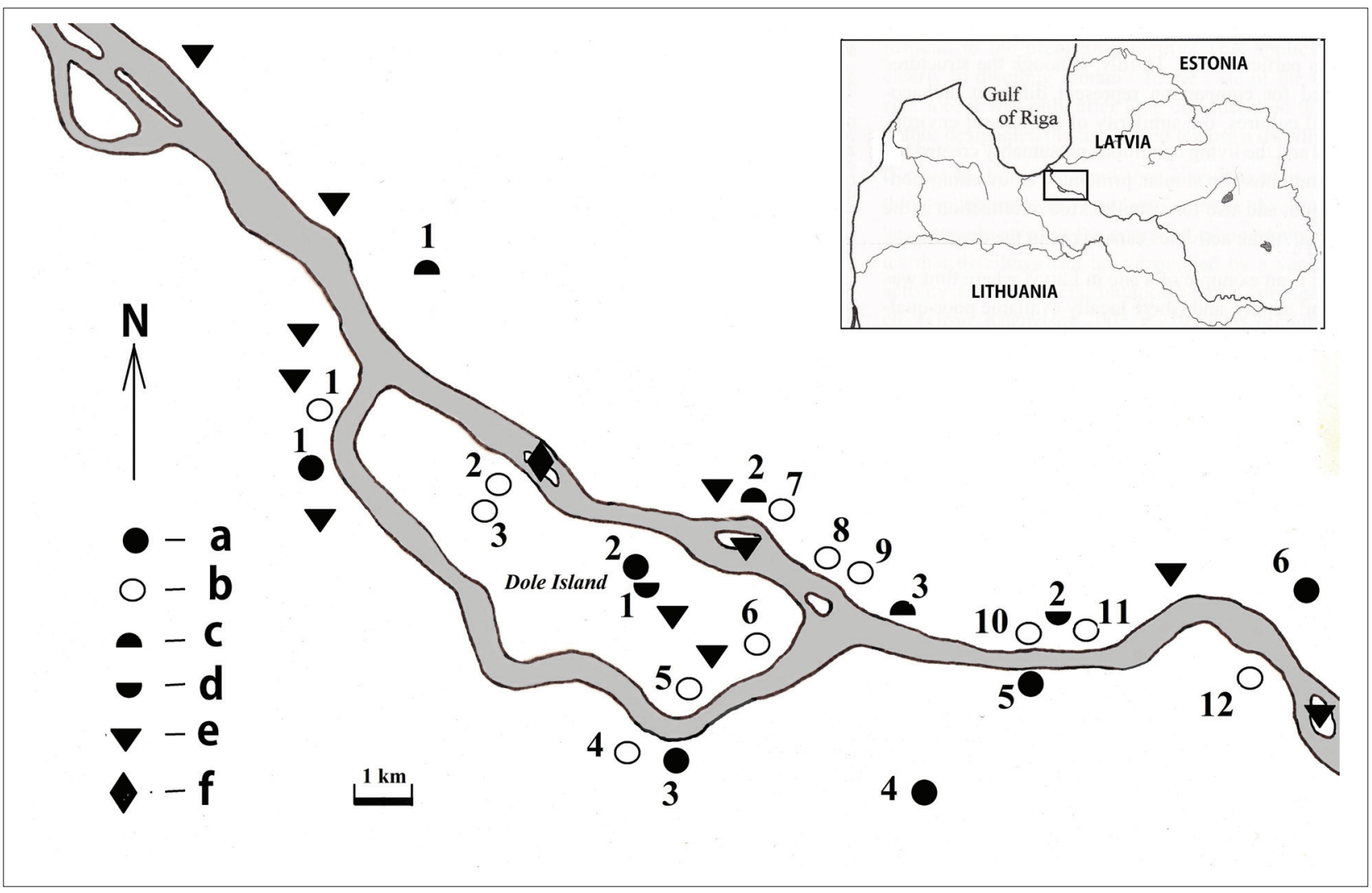

Figure 1. Bronze Age and Earliest Iron Age archaeological sites in the lower reaches of the Daugava. a) hillforts: 1. Saulieši; 2. Kivutkalns; 3. Klaṇgukalns; 4. Sakaiṇi; 5. Daugmale; 6. Vīnakalns. b) open rural settlements: 1. Pḷavniekkalns; 2. Vecdole Medieval castle site; 3. Jaunauči; 4. Strautnieki; 5. Vampenieši; 6. Rauši; 7. Vējstūri; 8. Salaspils Medieval castle site; 9. Zviedru skansts (in Swedish Shantz); 10. Laukskola; 11. Lipši; 12. Jaunlīve. c) barrow cemeteries: 1. Gilberti; 2. Vējstūri; 3. Reznes. d) flat cemeteries: 1. Ķivutkalns; 2. Lipši. e) stone work axe stray-find. f) Šķērssēklis (Parumba), a site of finds of Bronze Age artefacts.

finds in these settlements were the flint tools characteristic of the Late Palaeolithic and Early Mesolithic: knife-shaped blades, scrapers, arrowheads, etc, covered with a white or bluish-grey patina (Zagorska 2012, pp. 51-92).

The presence of people in the lower reaches of the Dauga$\mathrm{va}$, as is evidenced by stray finds of antler, bone and stone objects, also continued in the Mesolithic and Neolithic. In addition, judging by the increase in the number of finds in the Neolithic, especially in its late period, the presence increased (Zagorska 1998, pp. 30-37). However, so far, no human settlements have been discovered in this area. An indication of the possibility of a settlement somewhere in the area of the later Old Riga is a fragment of Combed Ware, typical of the Middle Neolithic, found during the excavations of the cemetery of the Riga Dom (Zagorska 1998, p. 34). It is also found in the cemetery at Vampenieši I on Dole Island (Šnore 1996, p. 111). The archives of the Department of Archaeology of the Latvian National Museum of History contain information about a possible destroyed Neolithic cemetery at Katlakalns Akmeņsala near Kalıuceplis, where human skeletons in a sitting and bent position have been discovered in earthworks, but there is no detailed information. A hollow chisel of green slate and a beaver tooth came to the museum from there (Denisova et al. 1985, p. 9; Atgāzis 1972, p. 44). Although the presence of people in the lower reaches of the Daugava in the Mesolithic and Neolithic has been established, the main populated areas of these fisher-hunter-gatherer communities were the shores of lakes and the rivers flowing into them, with ecological zones corresponding to the livelihood strategy (a classic example is Lake Lubāns).

\section{The Early Bronze Age (1800-1100 BC)}

The Vampenieši settlement at the top of Dole Island covers this period (Fig. 1.5b). In the 1960s and 1970s, during studies of the cemetery of Livs in the 10th to the 12th centuries at Vampenieši I, the remains of an older settlement were found (Šnore 1996, pp. 111, 113). In several hearths in this settlement, 280 fragments with a striated surface were found, as well as two fragments with the imprint of twisted cord. About 65 fragments were embossed with a string wound on a thin stylus, sometimes referred to as a barbed wire ornament. Of the last 45 fragments found in one of the hearths, they were characterised by a C-shaped pot with a 25 -centimetre-diameter mouth opening made 


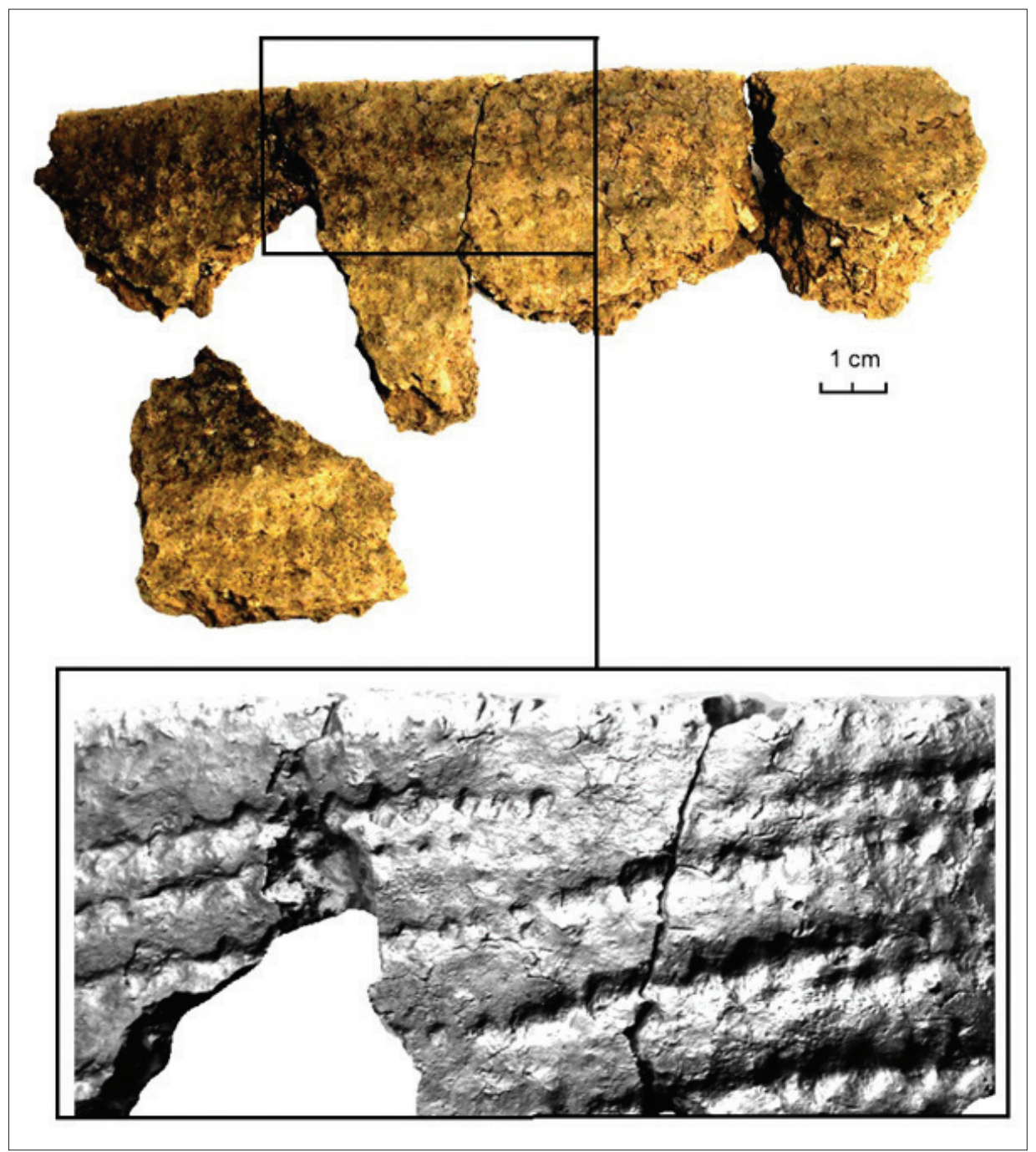

Figure 2. The edge of an Early Bronze Age pot with wrapped cord imprint decoration, Vampenieši settlement (photograph by Vanda Visocka, compiled by the author).

of coarse fabric with an admixture of crushed granite with 1.2-centimetre-thick walls. The outside of the pot was covered with a five-centimetre-long imprint of string wrapped obliquely, which, judging by the fact that all the fragments had this decoration, covered the entire surface of the pot (Fig. 2). From the other pot found in another hearth, a similarly decorated ten fragments could be reconstructed as the bottom of the vessel, which was about eight centimetres in diameter and 0.5 centimetres thick. Another ten fragments pointed to two more similarly ornamented vessels. A similarly decorated S-shaped pot was found in Lithuania at site 9 in the settlements at Šventoji, where the ${ }^{14} \mathrm{C}$ dates obtained indicated a time from 2328 to $1814 \mathrm{BC}$, the end of the Late Neolithic to the transition to the Bronze Age (Rimantiene 2005, p. 407, Abb. 301). In Lithuania, ceramics decorated in this way are associated with the influence of Trzciniec culture (1800-1200 BC), and refer to the Early Bronze Age (2000-1700/1650 BC) (Girininkas 2013, p. 96). The pottery found in the Vampenieši settlement is similarly dated. As is evidenced by the striated pottery found, a fragment of a so-called clay strainer, and a stone work axe, the settlement was also inhabited in the Late Bronze Age. In the lower reaches of the Daugava, the Vampenieši settlement is currently the only known Late Neolithic to Early Bronze Age transition residence, and that is why the archaeological data from the settlement are provided in such detail here.

It is possible that a settlement in the Late Neolithic and Early Bronze Age was also in the later site of Daugmale hillfort (Fig. 1.5a), because one whole and three fragmented straight-backed axes were found there, which, due to their symmetrical shape, are often considered as battleaxes (Fig. 3.3). To find a chronology of these axes, finds of 20 similar ones in Fatyanovo culture cemeteries are important (Krainov 1972, p. 46). According to the latest data from ${ }^{14} \mathrm{C}$ analyses, this culture covers the period from 2700 to 2500 (2300) BC (Krenke 2019), so the straightbacked axes were characteristic of the Late Neolithic. It is possible that derivatives of these axes date back to a later 


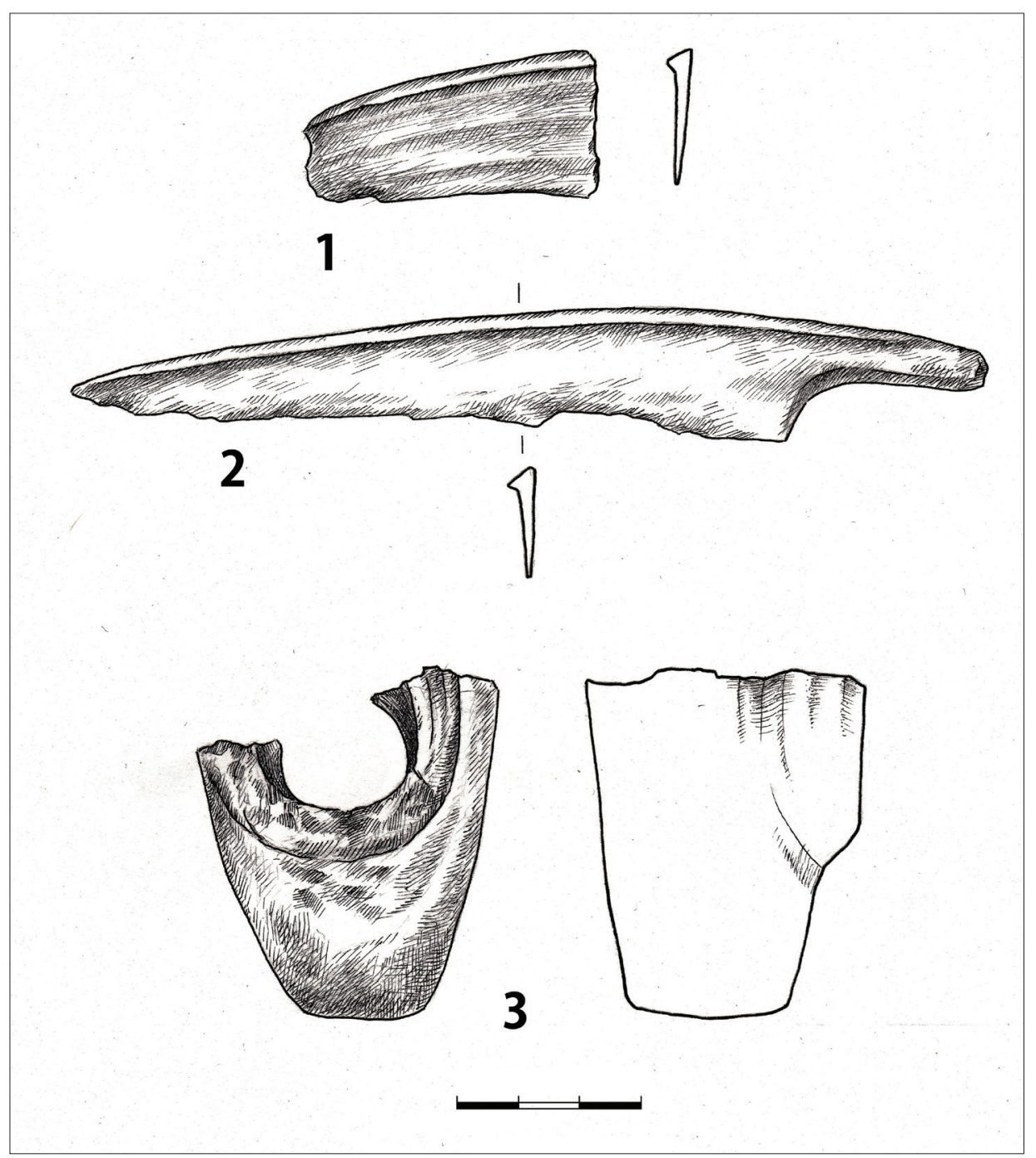

Figure 3. Early Bronze Age finds from Daugmale: 1, 2. bronze sickles; 3. stone straight-backed axe (drawing by D. Zemite).

time, to the end of the Neolithic, or even the beginning of the Bronze Age (Šturms 1936, pp. 16-17). In addition, two bronze sickles were found at the site of the Daugmale hillfort, one whole, but the other fragmented (Fig. 3.1, 2), which have analogues in finds from the Early Bronze Age in Scandinavia (Oldeberg 1974, Abb. 55, 348, 858, 1419, 2011, 2079).

There have apparently been some other settlements in the lower reaches of the Daugava, which are indicated by stray finds. In this respect, the location of the finds in the Daugava between the village of Parumba (Maruška) and Dole Island, where there was a ford (the Rumbula rapids), but in the middle of the river there was an islet called Šķērssēklis (Fig. 1.f). In the 1930s, while dredging the Daugava and digging gravel, a number of stone and bronze objects were found there, which were sent to the State Historical Museum (now the Latvian National Museum of History). The Early Bronze Age includes five straight-backed stone axes, one stone shoe-like hoe, one Nortiken-type bronze axe, and one flanged bronze axe. More detailed information on the conditions at the location is lacking, so the nature of the site remains unclear. Such a high concentration of intact finds in a small area calls into question the existence of the settlement on Šḳerssēklis Island. It is possible that these objects came to the shore with floodwater from washed-out settlements on the banks of the Daugava. However, taking into account about 60 existing Bronze Age stone objects, in addition to two intact bronze axes and a spearhead, there was probably a place of sacrifice in the water. The author has previously stated that intact stone axes may have been intentionally left in the fields as sacrifice (Vasks 2003). Whatever the explanation for the site, the finds point to the population of the lower reaches of the Daugava in both the Early and the Late Bronze Age. In addition to these finds, three straight-backed axes and two stone shoe last-like hoes have been found in the lower reaches of the Daugava. 
Outside the lower reaches of the Daugava, Early Bronze Age settlements are known in only a few places. One of them was on the lower terrace of the right bank of the Daugava near Lejasbitēni. In 1961, studies of the 3rd to 10 th-century cemetery revealed a 100-by-180-centimetre and up to 85-centimetre-deep thin rounded hearth area with a grey-brown and small charcoal mixed cultural layer, which contained several boulders decayed in the fire. Outside the hearth pit, the cultural layer had not survived. It was apparently thin, so in working the land over time, it was destroyed. A series of clay fragments were found in the hearth, which turned out to belong to one flat-bottomed pot. The pot was made of clay paste with an admixture of crushed granite, but its entire outside was decorated with horizontal imprints of twisted cord (Vankina 1980, p. 48). Judging by the bucket-shaped pot, clay paste and the horizontal arrangement of the decoration, it belongs to the Early Bronze Age.

Similar pottery was also found in the excavations of Raul Šnore in the Earliest Iron Age stone grave at Priekulu Kalna Kunči in 1942. Dozens of sherds were adorned with horizontal imprints of twisted cord (collection of Cesis History and Art Museum, CM/A 2864). Unfortunately, there is no data on the existence of the cultural layer, so it can be assumed that it was weak.

The remains of an Early Bronze Age settlement were also discovered at Matkules Tojāti on the right bank of the Abava, when in 1923, 1928 and 1976, the the Viking Agebarrows there were studied. The cultural layer was weak, only in one place was it 30-centimetres thick. Over 300 shards were collected, which came from pots made of clay paste with a strong admixture of crushed granite. There was decoration on some of the pieces of twisted cord, and less often of engraved lines. In addition to the pieces of pots, there were several pieces of the edges of amphorae. Flint arrowheads were also found, and flint fragments from a wedge-shaped axe (Ritums and Kalnina 2002, pp. 155-156).

As these examples show, the remains of Early Bronze Age settlements were discovered purely by accident by studying later sites. Apparently, due to their relative short life and/or small number of inhabitants, these settlements did not form a more pronounced cultural layer; therefore, they are rarely identified during the archaeological identification of the areas.

At the end of the Early Bronze Age, new funeral traditions entered the lower reaches of the Daugava: burials in stone cists and the cremation of the dead. The Reznes cemetery, with eight barrows, on the right bank of the Daugava near Salaspils, is important in this respect (Fig. 1.3c). Excavations in the Reznes cemetery were carried out by Eduards Šturms in 1933 and 1935 (Šturms 1936), and in 1958 and 1969 by Jānis Graudonis (Graudonis 1961; LA 1974, pp. 63-68). The barrows were made of light sandy soil with admixtures of fine coals, but in some cases pink clay sand was also used. In total, seven barrows $(1,2,4,5,6$, $7,8)$ in the cemetery were studied. The burial of the dead in several barrows took place in the Viking Age and in historical times, which shows that the importance of the cemetery as a special place remained for many generations. In the description of burial traditions and chronology in Reznes, both Šturms and Graudonis considered the skeletal burials at the base of the barrows to be the oldest. Above them was a layer with cremation pits, which in turn was covered with a layer of skeletons and cremations in stone cists. The stratigraphy of these three types of burial was also given a chronological significance. However, according to recent studies, the depth of burials in the barrows does not reflect the chronological sequence of burials in principle: the deeper, the older. The ${ }^{14} \mathrm{C}$ dates show that all three types of burials are synchronous. Thus, for example, burial in a stone cist, as is shown by the case of barrow 1 , took place as early as the 12 th or 11 th century cal BC, and was also practised in the Late Bronze Age in the 8th to the 6 th centuries cal BC. In turn, inhumation burials were characteristic both of the oldest period of the barrow and later. The same goes for the custom of cremating the dead. Judging by the dates of the large area of burnt bones in barrow 6, the oldest cremations took place in the 14th and 13 th centuries cal BC, and the latest in the 9th century cal BC (Vasks et al. 2021, p. 13).

Finds of artefacts at Reznes, as in other Bronze Age burials in the east Baltic, were scarce: only 44 items. Among them are some flint arrowheads and scrapers, a stone tool bore pin, a double-edged and simple work axe, bronze razor blades, tweezers, awls, a button, a spiral, an amber double button, a ring, pendants, and pieces of clay pottery (Graudonis 1961, Table I). For the first time, the placement of horse teeth, even a whole series of jaw teeth, was found in barrow fills, and less often in separate graves. On barrows 4,5 and 6 , they were found in eight places. The exception was barrow 2, where horse teeth were found in 136 locations in all layers of the barrow fill. An exception is barrow 8 , where a bull's tooth was placed. Later, a similar ritual use of horse teeth was recorded at Kivutkalns (Denisova et al. 1985, Table 6), Kalnieši (Vankina 1962), and Vējstūri (Zariņa 1987, pp. 19-21) cemeteries near the Daugava. This tradition has not been established so far outside the lower reaches of the Daugava.

A second Early Bronze Age burial site has been excavated at Salaspils Vejjstūri on the right bank of the Daugava, a few kilometres down from Reznes (Fig. 1.2c). Here, of the 1.6-metre-high barrow (diameter ten to 12 metres), only the southeast section, in which a one to 1.2-metre-wide stone double circle section was revealed, has survived. The outer circle was loaded with 20 to 30-centimetre boulders, stacking them in two or three layers, but the stones 
in the inner circle were in one layer. The diameter of the circle is estimated to be ten to 12 metres. Three cremations were discovered on the outer edge of the stone fence. At a slightly higher level, there were three inhumations, which the author of the excavations Anna Zarina (1987) considered to belong to the barrow. In addition, a horse's tooth was found in the fill of the barrow, as was mentioned above. The analysis of one cremation ${ }^{14} \mathrm{C}$ showed the time 1376-1018 cal BC with a median 1178 cal BC (Lab.code Poz-112722), hence the 12th century cal BC. As in Reznes, judging by the layer of coal, the site of the Vejjstūri barrow was first burnt. The Vējstūri barrow differs from Reznes in creating a stone circle.

\section{The Late Bronze and Earliest Iron Age $(1100-500-$ to $1 \mathrm{BC})$}

During this period, a new type of settlement appeared in the east Baltic: fortified settlements or hillforts (hill-top settlements). Six hillforts inhabited in the Late Bronze Age are known in the lower reaches of the Daugava. The sites chosen for them were either headlands at the mouth of river tributaries, formed by the Daugava and the river flowing into it, as at Kivutkalns (Fig. 1.2a) and Daugmale (Fig. 1.5a), or a standing moraine hill, as at Vīnakalns (Fig. 1.6a), Klangukalns (Fig. 1.3a), Saulieši (Fig. 11a) and Sakaiņi (Fig. 1.4a) hillforts. Between 1967 and 1975, excavations were carried out at the site of Salaspils Medieval castle (Fig. 1.8b), and traces of a population attributable to the first millennium BC (possible protective fence pole pits, striated pottery, fragments of stone axes, flint drill, bone stilts and a pin) were discovered. Ādolfs Stubavs, the head of the excavations, believed that there was a fortified settlement here, but due to the lack of archaeological evidence, it belonged to a temporarily inhabited hillfort (Stubavs 1970; 1971). Taking into account the scant evidence, the author of the article refrains from agreeing with Stubava's opinion, and rather sees the signs of an open rural settlement here ${ }^{1}$.

Initially, the inhabited plateaux of the hillforts were protected by simple wooden fences, but over time more and more complex structures were built for protection: earth ramparts with built-in wooden reinforcements or stone piles at their core, wooden fortifications, and sometimes erect steeper slopes with clay or stone. The most extensive evidence of fortifications and buildings was obtained at

\footnotetext{
1 The author of the article does not support the division of settlements into fortified and unfortified settlements, which was previously accepted in Latvian archaeology, but considers that in the Bronze Age and the Earliest Iron Age they can be divided into hillforts (hill-top settlements) and open rural settlements. The latter could also be (and probably were) protected by a fence, even of a palisade type. This is evidenced by the examples of Kerkūzi and a couple of other open settlements (see Vasks 2005, p. 29).
}

Kivutkalns, Vīnakalns and Klangúukalns. At Kivutkalns, for example, the width of the fortification zone reached seven to ten metres, at Vinnakalns six to ten metres, including 650 to 700 square metres, and 420 to 460 square metres, of living space respectively. In this area, ten to 20 -square-metre large rectangular pole buildings were built, which were annularly joined to the fortifications. At first, the central part of the plateau remained undeveloped, but over time, buildings were built there as well. Both at Kivutkalns and Vinakalns, as well as in several other hillforts of this period, there was a tendency to expand the residential plateau by moving the fortifications to the outside. The need for more living space obviously had demographic reasons: an increase in the number of people (Vasks 2015, pp. 107110). The limited area of the hillfort plateaux, especially with the increase in the number of inhabitants, contributed to the increased formation of a saturated cultural layer. At Klangigukalns, the thickness reached one metre, at Vinakalns one to 1.5 metres, and at Kivutkalns as much as three metres. In addition to the remains of constructions, the cultural layers of these hillforts also provided a rich range of artefacts and ecofacts. Among the artefacts were objects in stone, bone, horn, clay and bronze. Most of the found ceramics, up to $90 \%$, were fragments of pots with a striated surface. Smooth ceramics were represented in small numbers, but very few (about 1\%) textile ceramics (Graudonis 1989, p. 49; Vasks 1991, Table 5).

Open rural settlements also continued to exist in the Late Bronze Age. On the right bank of the Daugava, they are known at Lipši (Fig. 1.11b), Vējstūri (Fig. 1.7b), Salaspils (Fig. 1.8b), Zviedru skanste (Fig. 1.9b) and Laukskola (Fig. 1. 10b); on the left bank at Plavniekkalns (Fig. 1.1b), Strautnieki (Fig. 1.4b) and Jaunlive (Fig. 1.12b); but on Dole Island on the site of Vecdole Medieval castle (Fig. 1.2b), Jaunauči (Fig. 1.3b), Rauši (Fig. 1.6b) and Vampenieši (the settlement was inhabited as early as the Early Bronze Age); hence, in total, in 12 places altogether. The existence of settlements was evidenced by the striated pottery and stone work axes found. As the cultural layer corresponding to the settlements was not preserved, due to agricultural activity in later periods, data on buildings and farms were missing. It can only be concluded that, as in the Early Bronze Age, also in this time, unlike hillforts, the cultural layer of open rural settlements was thin and weak. (For more information on these settlements, see Vasks 1991, pp. 131-174). There are also possible settlements near Reznes, Vējstūri and Lipši cemetery, so there should be a total of 15 settlements.

In the Late Bronze Age, in the lower Daugava, burials continued in the Reznes and Vējstūri barrow cemeteries, but there was also a tradition of burying the dead in grave pits dug in the ground, flat cemeteries. One such flat cemetery with skeletons and cremations was fully explored at Doles Kivutkalns (Fig. 1.1a). The situation of the cemetery 
is unique to the whole of northeast Europe, namely, the Kivutkalns hillfort was built directly on top of a cemetery. In his time, J. Graudonis dated the beginning of the hillfort to the 9th or 8th century BC, but stratigraphically the older cemetery undoubtedly to the third and fourth quarters of the 2 nd millennium BC. Subsequent ${ }^{14} \mathrm{C}$ analyses of burial bones showed that the cemetery was later, and was used from about 800 to $680 \mathrm{BC}$, but the hillfort was created around $650 \mathrm{cal} \mathrm{BC}$, and inhabited until the second half of the 2nd century AD (Vasks and Zarina 2014). It is possible that there was a similar flat cemetery at Salaspils Lipši on the right bank of the Daugava (Fig. 1.2d) (Vasks 1991, p. 153).

Several similar cemeteries are known in the eastern part of the Lielupe basin, of which $\operatorname{six}{ }^{14} \mathrm{C}$ dates were obtained in the more studied cemetery at Rundāles Ziedonskola, and indicated a time from the 8th to the 6th centuries BC. However, the flat cemeteries near the Daugava appeared earlier. Thus, in the Raganukalns cemetery on the island of Saka near Jēkabpils, calcined bone nest 1 showed 1233-1049 cal BC (probability 93.9\%), with a median of $1155 \mathrm{cal} \mathrm{BC}$ (Ciglis and Vasks 2017, Table 1). Burials in Gilberti, Dreilini parish, can be attributed to the-Earliest Iron Age (Fig. 1.1c). In 1929, diggers dug up human bones on a sandy hill when digging sand. Two bronze temple ornaments and one fragment of an ornament with a spiral middle part and spoon-shaped ends, dating from the 2nd to the 1st century BC, were found on one of the six skulls. Judging by the scanty information, it may have been a barrow built of sand (Ciglis 2010).

The Late Bronze Age in the lower reaches of the Daugava is also characterised by stray finds, most of which are simple stone axes. In the examined area, 55 such axes with a shaft-hole are listed, as well as three stone wedge-shaped axes. (Fig.1.e shows the narrowed area of the lower reaches of the Daugava; therefore, not all the finds mentioned are marked). The above-mentioned Škerssēklis in the Daugava between Dole Island and the village of Parumba (Maruška) stands out especially, where 15 shaft-hole axes and one wedge-shaped axe were found. These finds of axes mark places of human activity, where hitherto unknown dwellings and ancient burial sites should be found (the shores of Lake Baltezers, Lake Jugla, the shores of the River Jugla).

The subsistence strategy in the Bronze Age in the lower reaches of the Daugava

Although the east Baltic was still dominated by the gatherer economy in the Neolithic and at the beginning of the Bronze Age, the first signs of animal husbandry and farming can be seen in the Middle Neolithic. This is evidenced by the finds of livestock bones in the Zvidze settlement in the Lubāna wetland. It is important to note here that the settlement was inhabited from the Late Mesolithic to the Middle Neolithic, when the settlement ended. Of the total number of identified animals (551), 49 animals (8.9\%) were livestock. These 49 animals include 25 cattle, 18 pigs, and six sheep or goats (Loze 1988, Table 22, p. 114). In the Late Neolithic and at the beginning of the Bronze Age, however, the number of domestic animals in settlements in the Lubāna wetland at Eiņi, Abora I and Lagaža did not exceed $3 \%$ of the total number of animals (Loze 1979, Tables 12-14). The first signs of agriculture also appeared in the Middle Neolithic. Thus, half the charred barley grain in the Kreiči settlement was found near a hearth. Barley and hemp pollen have also been found in the Zvidze settlement, which is also known from the settlement of Šventoji on the Lithuanian coast. Ilze Loze also points to finds of tillage tools: hoes in the settlements of Zvidze, Sārnate and Šventoji (Loze, 1997, pp. 31, 34). Corded Ware culture (CWC) spread in the east Baltic in the Late Neolithic. The economy of this culture is believed to have been based on agriculture and animal husbandry, although it also hunted (Loze 2001, pp. 99-100). In fact, however, specific data on tribal farming in the east Baltic are very scarce: in Estonia, a pig bone in the Loona settlement dates back to 2700-2500 BC, and one cattle bone was found in the CWC burials of Ardu, Sope and possibly Karlova (Lõugas et al. 2007). It can only be stated that traces of this culture, primarily boat axes, are found on moraine, alluvial or glaciolimnic sand deposits, thus in areas potentially suitable for the development of agriculture (Vasks 2015, pp. 66-67).

In recent years, reasonable doubts have been expressed about the cultivation of crops in the Neolithic. The Lithuanian researchers M. Grikpèdis and G. MotuzaiteMatuzevičiūtè assessed critically the validity of the Neolithic agricultural evidence expressed earlier, reviewing the results of both pollen and plant macro-residue analyses, as well as the feasibility of using tillage-related tools in the east Baltic. They found that pollen alone, without other evidence, could not be a sufficient basis for proving crop cultivation or farming. It is not always possible to determine their affiliation with wild or domesticated grasses (millet, hemp, barley, wheat, rye) by the size and shape of the pollen. Sediment sampling techniques are also important for accurate results. The authors note that the shortcomings of this procedure, as it was during the USSR, could have led to the entry of pollen from the highest, i.e. the newest, layers of the sediments into the deepest, and therefore the oldest. The belonging of macrobotanical remains, i.e. plant seeds, to crops in the Neolithic settlements of Šventoji is also questioned. In addition, none of these seeds, which are alleged to be considered as crops, have been analysed for ${ }^{14} \mathrm{C}$ age. According to these researchers, the existence of agriculture cannot be proven 
by the presence of wooden hoes, shovels and other earthmoving tools in Neolithic settlements, as they could have been used for collecting wild plant roots or in other foraging work. Accordingly, agriculture can be talked about only from the Bronze Age (Grikpedis and MotuzaiteMatuzevičiūtè 2018).

Although the lower reaches of the Daugava are suitable for the development of both animal husbandry and agriculture, the evidence obtained there about these activities in the Early Bronze Age is scarce. The ${ }^{14} \mathrm{C}$ calibrated dates of the three oldest horse teeth found in barrow 2 at Reznes showed a time from 1225 to $1028 \mathrm{cal} \mathrm{BC} \mathrm{(Poz-111895),}$ 1211-1020 cal BC (Poz-111894) and 1225-1028 cal BC (Poz-118254) respectively, hence, the very end of the Early Bronze Age. The two already-mentioned stone shoe last-like hoes indicate tillage at this time. No evidence of animal husbandry and farming has been obtained either at Vampenieši or in the few known Early Bronze Age settlements outside the lower reaches of the Daugava

There is much more detailed data on farming from the Late Bronze Age. They are mainly obtained in the fully explored Kivutkalns and Vīnakalns, as well as the Klaṇgukalns hillfort. The number of livestock bones (cattle, pigs, horses, small cattle-sheep/goats) in the composition of animal bones was $71 \%$ at Klaṇgukalns, and $76 \%$ at Vīnakalns. At Kivutkalns, the number of livestock bones reached 94\%, which is an unusually high indicator, even in comparison with the data obtained in Iron Age and Medieval settlements (see the case of Kivutkalns below). Cattle was used most in the diet (38\% to $47 \%$ of bones), followed by pigs (21\% to $26 \%)$, sheep and/or goat (12\% to $18 \%)$. Although horses, as is shown by the parts of a bridle found, were used in transport, $16 \%$ to $20 \%$ of the bones of these animals in the total bone mass of livestock indicate their use in food (Graudonis 1967, Table 5; 1989, Tables 6, 8). There is no reliable evidence that the milk of cattle, sheep, goats, and maybe even mares, was used in the diet. Previously, perforated clay cylinders, so-called strainers, were considered to be evidence of milk processing in the Late Bronze Age, fragments of which were found at Klangikukalns and Kivutkalns, as well as elsewhere in Latvia, but according to the latest research, these clay formations had a different use; most likely, they were used to preserve glowing coals in a hearth (Vasks 2018). Lipid analyses of Bronze Age earthenware could shed more light on the use of dairy products.

Significant evidence of the cultivation of crops in the lower reaches of the Daugava in the Late Bronze Age is provided by the large amount of charred grains found in the Kivutkalns hillfort. Among the 14 samples analysed were double-grain wheat or emmer (Triticum dicoccum), barley (Hordeum sativum), millet (Panicum miliaceum), beans (Vicia faba), and peas (Pisum sativum). Wheat, which dominated the Kivutkalns grain samples (nine out of 12), unlike barley and millet, requires more careful care, including fertilisation. Millet and peas were present in 11 samples, and beans in three. Judging by the pronounced presence in the samples, white pigeon (Chenopodium album) was also used in food, which was detected in six samples out of 14 , as well as oatmeal (Avena fatua) (11 samples) (Graudonis 1989, p. 72). The weed seeds found in the samples, chickweed (Stellaria media), corn spurry (Spergula arvensis), white campion (Melandryum album) and common sorrel (Rumex acetosa), indicate longstanding fields. Although no remnants of furrows left by a plough have been found in the lower reaches of the Daugava, such as those found at Dievukalns near Lielvārde (Zarina 1982, pp. 68-69), the possible use of a plough is indicated by a stone ploughshare found at Kivutkalns (Graudonis 1989, p. 26, Table 7.11). In agriculture, simple stone axes were widely used for clearance (98 axes and fragments of them were found at Kivutkalns alone). The importance of cereal food is indirectly indicated by the two-handed upper grindstones found at Kivutkalns, which were more efficient than single-handed ones (out of 83 upper grindstones, 12 were two-handed, the rest were single-handed) (Graudonis 1989, p. 28). It should be noted that nowhere else are two-handed grindstones found in Late Bronze Age settlements. Taking this into account, and the large amount of charred grain found at Kivutkalns, it should be concluded that agriculture on Dole Island was widely developed. As the dominant farming system in the Bronze Age was slash-and-burn, it contributed to the reduction of forest areas near hillforts in the lower reaches of the Daugava. This was particularly evident on Dole Island, where the number of forest animals declined sharply. This explains the unusually large predominance (94\%!) of livestock bones over game at Kivutkalns hillfort. Usually, $75 \%$ of animal bones found in Late Bronze Age hillforts belonged to livestock (Vasks 2015, p. 117).

In the hillforts in the lower reaches of the Daugava, 25\% to $30 \%$ of the bones of animals used for food belonged to hunted animals. The exception is Kivutkalns, where, due to the mentioned conditions, the number of these bones was only $6 \%$.

Elk, wild boar, roe deer, hare, bear and bison, but mostly beaver, were hunted, the amount of bones of which was $55 \%$ at Kivutkalns, and $65 \%$ at Vīnakalns. The prevalence of beavers in hunting was apparently determined by three factors: the meat, the beaver gland secretions that are still used in treatment today, and, most importantly, the fur. Although bones of small fur-bearing animals (martens, squirrels) have not been found, the horn arrowheads found at Kivutkalns, with a flattened tip for shooting the animals without damaging the fur, indicate their hunting. 
According to fish residue layers up to 30 centimetres thick discovered near the hearths at Kivutkalns, fishing was widely practised. An analysis of these remains showed that 14 species of fish were caught in the Daugava. Pike-perch were caught the most (39\% of analysed bones), followed by sturgeon $(23 \%)$ and bream (17\%). Pike, perch, catfish, etc, were also caught. Judging by the size of the fishbones, mainly large fish were caught (pike-perch up to 60 centimetres, sturgeon up to 360 centimetres, catfish up to 200 centimetres, pike up to 130 centimetres long). The shells of river mussels (Unio pictorum) found in large quantities at Kivutkalns and Vinnakalns indicate the use of these molluscs for food (Graudonis 1989, pp. 80-81).

\section{Bronze processing and exchange}

In addition to cattle breeding and crop cultivation, the Bronze Age is characterised by another innovation, the acquisition of skills displaying bronze objects and metalworking. The oldest bronze objects in the east Baltic come from Lithuania and Estonia, where they can be attributed to period I of the Bronze Age (1800-1500 BC); in Latvia they appeared in period II (1500-1300 BC). The oldest evidence of bronze processing in Latvia was obtained at the Lagaža settlement in the Lubāna wetland, dating from the Early Bronze Age, where fragments of four bronze smelting clay crucibles were found (Loze 1972, p. 63) ${ }^{2}$. In the lower reaches of the Daugava, the oldest are one Nortikentype and one flanged bronze axe from the Rumbula rapids near Parumba, which can be attributed to period III. Local bronze processing in the area in question began only in the Late Bronze Age, and played a key role in the prosperity of local communities. This is evidenced by the bronze smelting clay crucibles and moulds found in the hillforts. There are about 30 such hillforts in the east Baltic, 17 in Latvia. In the lower reaches of the Daugava, evidence of bronze processing was obtained at four hillforts (there are nine in total near the Daugava): Saulieši, Kḷaņgukalns, Vinnakalns, and especially Kivutkalns. The crucibles had a bowl-like shape with a rounded base and a diameter of six to ten centimetres (Fig. 4.1). Three-legged crucibles have also been found at Kivutkalns, which apparently indicates a more sophisticated bronze processing technique (Fig. 4.2). There were two types of moulds, double-sided and one-piece ones. Judging by the fragments of double-

\footnotetext{
2 Vytautas Podènas and Agnè Čivilyte have recently expressed doubts about the suitability of these crucibles for melting metal, and their belonging to the Early Bronze Age (Podenas and Čivilyte 2019). However, bronze remains have been preserved on one of the bowl-shaped crucible fragments, indicating metal melting (Loze 1972). Similar flat bowl-shaped crucibles were used in the Late Bronze Age, for example, at Brikuli hillfort (Vasks 1994, p. 33.). In order to find a chronology of the Lagaža crucibles, new research is needed in the settlement, but until there is none, the author retains the current date.
}

sided moulds, spearheads and socketed (including Akozino-Mälar-type) axes were cast in them, and some other items (Fig. 4.5). Bronze rings of various sizes were cast in one-piece moulds: judging by the size, they were necklaces with a diameter of nine to 18 centimetres, as well as bracelets, and bracelet-like rings with a diameter of four to eight centimetres (Fig. 4.3,4). The number of mould fragments used for casting them is several times higher than for double-sided mould fragments. For example, at Kivutkalns hillfort, out of 544 fragments of moulds, 494 were from one-piece moulds for casting rings, and only 50 were from moulds for axes, spearheads or other objects. In another bronze processing centre, Brikuli hillfort near Lake Lubāns, only 21 of the 248 fragments of moulds were from double-sided moulds, but the other 227 fragments were from one-piece moulds for casting the mentioned rings. Thus, $91 \%$ to $92 \%$ of all mould fragments came from moulds for rings. Even considering that the removal of a ring from a one-piece mould involved breaking it, thus creating a large number of pieces, it cannot be overlooked that rings were made in large numbers. These bronze casts are considered to be ornaments: necklaces and bracelets. However, the large number of moulds also allows for a different explanation of their meaning. In this connection, the Staldzene hoard (7th century BC), of Scandinavian origin, is interesting, which, in addition to bronze ornaments and fragments of them, also contained 34 bronze rings with open ends. Their diameter was eight to 11 centimetres, but the cross-section of the arc was round, rectangular or flattened. Some of the deposited rings, especially at the open ends, had defects in the casting that were not ground. Due to the lack of a finish after removal from the mould, these robust rings differed sharply from other carefully, even exquisitely, designed ornaments, so they cannot be included in the category of ornaments, but ingots. Apparently, they were used as a form of storage and transport of metal, and/or as an exchange equivalent, as a kind of 'commodity' (Vasks and Vijups 2004, pp. 9-10). Jewellery-like ingots, such as loop neck-rings, are also found elsewhere in Bronze Age hoards in Europe (Harding 2000, pp. 218-219). In the Viking Age, armband-like spirals made of silver served a similar purpose alongside cast silver bars (Urtāns 1977, p. 109).

The amount of bronze working in each hillfort can be judged by the ratio of the number of finds of crucible and mould fragments to the number of other artefacts found (excluding pieces of earthenware). A total of 191 fragments of crucibles and 544 fragments of moulds were found at Kivutkalns, coming to 735 items, which is $27 \%$ of the total number of 2,700 artefacts found. They accounted for $24 \%$ of the 131 artefacts at Kḷngukalns, while at Vinakalns, crucibles and moulds (29) accounted for 10\% of the 280 artefacts. One fragment of a crucible has been 


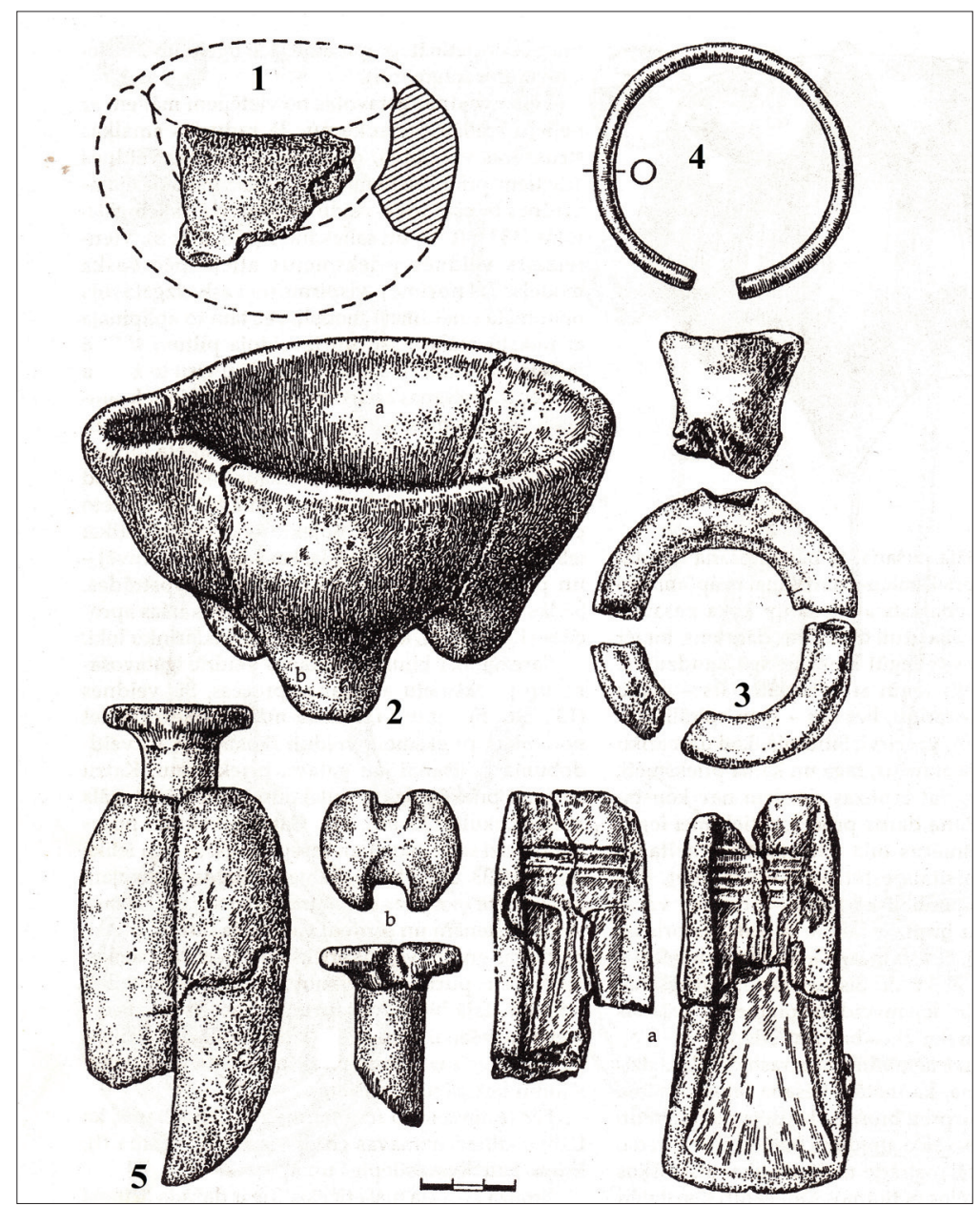

Figure 4. Bronze processing accessories and a bronze armband-like ring, Kivutkalns hillfort (Graudonis 2001, Fig. 133); 1. a crucible fragment and a reconstruction; 2. a three-legged crucible; 3. a mould with a filler funnel for an armband-like ring; 4. a bronze armband-like ring; 5 . double-sided mould for a soceted axe: a) an overview of the mould form; b) a core for socket forming; c) both sides of the mould with an imprint of an axe.

found in the destroyed Saulieši hillfort, together with the collected ceramic fragments, but this confirms only the bronze processing, and does not give an insight into the scope of the activity in this residence. Evidence of bronze processing has been found to a much lesser extent in the other five hillforts by the Daugava (Vasks 2007, p. 72).

A necessary condition for the existence of bronze processing centres was a regular influx of bronze, which could be provided only by long-distance exchange. In this respect, the settlements in the lower reaches of the Daugava were in a more favourable position than areas in the east Baltic, which were remote from major waterways. The River Daugava became an important communication route as early as the Stone Age, especially in connection with the exchange of amber in the Middle and Late Neolithic (Vasks 2015, p. 75). A new increase in the use of this waterway took place in the Late Bronze Age, when contacts were established between Scandinavia (central Sweden) in the west and the Volga-Kama metallurgical centre in the east. These contacts are shown clearly by the distribution of Akozino-Mälar-type axes in Eastern Europe, where two centres of their distribution stand out. One is in Scandinavia, especially in central Sweden, where about 115 have been found, and the other is in the Volga-Kama district, where 262 such products are known (Kuz 'minych 1996, Abb. 2, Taf. 2). They are also found in the lands between these centres, including the east Baltic. In Latvia, four Akozino-Mälar-type axes were found: two of them near the River Daugava (one at Klangukalns, the other at Krustpils), and the other two in the Daugava basin (at the Zvejsalas settlement by Lake Lubāns, and by Lake Ludza) (Vasks 2015, p. 129). Considering the prevalence of these axes, one of the communication routes would be identifiable along the Volga and the Kama, and further along the Daugava. The crossing of the Baltic Sea in the Bronze Age is indicated by the stone ship-settings typical of northern Europe, especially Gotland. They are also known in five places near the River Roja in north Kurzeme. For the stone ship-setting at Lubes Bilavas, the ${ }^{14} \mathrm{C}$ date of one cremated burial indicated a time from 1398 to 1112 cal BC (Period III), but for the second cremated burial, the period from 937 to $806 \mathrm{cal} \mathrm{BC}$ (period IV-V) (Wehlin 2013, Table 4.2). 
Thus, shipping across the sea began in the Early Bronze Age, and continued into the Late Bronze Age. The alreadymentioned Staldzene hoard, as well as the Tehumardi hoard, with bronze products typical of northern Europe, on the Sorrve Peninsula in Saaremaa, clearly mention the two stone ship-settings. It is important to note that the items in both hoards were broken, damaged and fragmented; therefore, they are included in so-called 'scrap deposits' intended for remelting. The Irbe Strait was like a kind of gateway to the River Daugava, through which sailors could go further east. Consequently, the inhabitants of the lower reaches of the Daugava had every opportunity to get involved in the exchange of bronze and metal processing. This involvement is evidenced by the establishment of bronze processing centres in Kḷangukalns, but especially at Kivutkalns. Several hillforts on the banks of the Daugava were also involved to a lesser extent in bronze processing, and thus less in exchange communication (Vasks 2007, pp. 66-73).

\section{Society}

Compared to Middle and Late Neolithic fisher-huntergatherer societies, which can be described as trans-egalitarian in terms of social relations, i.e., in which the former egalitarianism has disappeared, but formalised elite leaders and a permanent social ranking system have not yet been established (Zvelebil 2006, p. 185), in Bronze Age farming societies, these relationships became more complex. Firstly, it is reflected in the introduction of new burial traditions; secondly, it is indicated by the stratification of habitats; and thirdly, it is evidenced by the treatment of bronze and related activities.

The population also changed in the Bronze Age. The population in the Early Bronze Age in the lower reaches of the Daugava is indicated by the settlement at the later site of Daugmale hillfort, the settlement at Vampenieši, settlements corresponding to the Reznes and Vejjstūri cemeteries, two shoe last-like hoes found at Ķekava Pulkarne and Kug̣i, and two straight-backed axes from Rīga Šampēteris and Dole Island; thus, a total of eight population points. In the Late Bronze Age, in the area under study, there were six inhabited hillforts and 12 open settlements. The settlements also had to be close to Salaspils Reznes, Vējstūri and Lipši cemetery, so the possible number of settlements could be 21 . In addition, simple stone axes were found in 11 places, which indicates the proximity of the settlement. Some of them are probably related to nearby settlements, for example, three axes found near Pḷavniekkalns settlement and Saulieši hillfort, two axes found near Vampenieši and Rauši at the top of Dole Island, and one axe found near Vējstūri settlement. However, five stone axes could be related to non-fixed open settlements, therefore adding up to 26 population points (Fig. 1.e).
However, these data are speculative in nature, as, firstly, Early Bronze Age and Late Bronze Age settlements may have been more at the expense of hard-to-fix open settlements. Secondly, the number of settlers is important. If around 40 to 60 inhabitants are estimated in hillforts (Vasks 2015, p. 109), then there are no such data on open settlements. It can only be assumed that the number of inhabitants in open settlements was smaller compared to hillforts. However, despite the conditionality of the above data, there is no doubt that in the Late Bronze Age, the population density in the lower reaches of the Daugava increased dramatically, based on the above-mentioned number of settlements in the Early Bronze Age (8) and the Late Bronze Age (26). The increase in the number of inhabitants is indicated both by the concentration of buildings on the Kivutkalns plateau, and by the earthworks to enlarge the plateau at Vinakalns. In turn, at Klangigukalns, the area outside the fortification ramparts began to be inhabited (Graudonis 1989, p. 89). Attempts to enlarge the plateau of building construction are also typical of other fortified residential sites in the Late Bronze Age, for example, at Brikuli hillfort at İdeņa, and Krievukalns at Skrunda (Vasks 2015, p. 114).

The formation of new social relations is evidenced by the introduction of new funeral traditions, namely, the construction of burial mounds, or barrows; and a new type of burial, cremation, appeared alongside the inhumation of the dead. Barrow cemeteries were located far from places of residence, which probably indicates the idea of the separation of the 'communal' living space from the mythical sacred world where the ancestors lived. The construction of barrows is characteristic of new, expanding and socially differentiated societies, for which it was important to strengthen their territory and social position in this purely symbolic way. Unlike flat cemeteries, barrows were visible from a distance, and could have a mnemonic significance, namely, to promote associations of the historical memory for contemporaries, and especially for future generations.

Reznes cemetery, with eight (in the Bronze Age it could have been more) barrows in a row at the highest point of the former island in the Daugava, is a clear example. By building barrows from earth and stones, and presumably using wooden constructions, a symbolic model of a house or even a settlement was created for the ancestors. The cremation of the dead is probably related to the introduction of new notions in which the mortal human body, the corpse, is separable from the soul, or spirit, which is immortal. The fire, in this case, is what is able to transform the original substance into a new quality (Vasks 2009, pp. 94-97). The construction of barrows and the cremation of the dead, as is shown by research in Pukuli cemetery, were known already in the 17th and 16th centuries BC in southwest Latvia (Ciglis, Vasks 2017, p. 48). In the lower reaches of the Daugava, judging by the latest research on 
the chronology of the Reznes barrows, these funeral traditions began later, in the 14 th century.

Many deceased were usually buried in barrows in Bronze Age cemeteries, as was the case in Reznes, from a few dozen to several hundred over several centuries ${ }^{3}$. Those buried in the barrows can obviously be considered to have belonged to the same family or branches of it for many generations. Burial in such a barrow, which has been used for many generations, can obviously be explained by the desire to emphasise genealogical continuity, thus legitimising one's historical right to the family territory. Even when the family succession ended, for various reasons, it could symbolically be restored through its former burial site. It seems that this happened in the case of barrow 2 in Reznes cemetery, when in the 7th century BC, five centuries after the beginning of burials in this barrow, a 'leader's tomb' was built, a central cist with the dead buried in it (Fig. 5). The oldest burials were destroyed during this act. It is significant in the 7th century, because around this time, when the Daugava became a strategic transit route, exchange relations across the Baltic Sea between Scandinavia and the Volga-Kama Ananjino cultural area became more active. It should also be noted that in the 7th century BC, a bronze processing centre was established at Kivutkalns hillfort. In this situation, a new elite, with leaders who were involved in exchange activities, apparently formed in the lower reaches of the Daugava.

Flat cemeteries are also known in the lower reaches of the Daugava: one at Kivutkalns, and another possibly at Lipši. Judging by the arrangement of the cemetery at Kivutkalns, it can be seen that some graves were arranged with more care and work than others (stone constructions, clay coverings, specially found white sand deposits in grave pits, and combinations of these elements). This suggests that there were people with a higher social status in the society that buried their dead in Kivutkalns cemetery.

Changes in social relations at the beginning of the era of farming and cattle breeding were also reflected in the nature of habitats, namely their differentiation in open settlements and hillforts. The open settlements established in the Early Bronze Age, as the example of Vampenieši shows, continued to exist in the Late Bronze Age, when new ones appeared as the population density increased. Hillforts were an innovation typical of the Late Bronze Age. Unlike open settlements, which do not have signs of externally visible fortifications, hillforts are characterised by the difficult access to the site, ditches, escarped slopes, and ramparts with built-in wooden structures. To an even greater extent than building barrows, the construction of

\footnotetext{
3 However, only one burial in a stone cist was discovered in barrow 1 in Reznes cemetery. Of this large barrow, 24 metres in diameter and 1.75 metres high, only the central part was excavated, so the question of possible burials on the periphery cannot be answered; the barrow was destroyed in 1957.
}

hillforts required considerable resources: both building materials (stones, timber, clay), labour, and the ability to organise the construction work. Kivutkalns, Vinakalns and Klangukalns stand out with their strong fortifications. Such massive fortifications seem unmatched to the threat of attack at the time and the practical possibilities to overcome them. Apparently, the construction of mighty fortifications also had a purely psychological significance: to show the ability of the elite to build them. Settlements created in this way had to leave contemporaries with the impression of a monumental and impregnable building (Vasks 2007, pp. 34-36).

Depending on the extent to which bronze was treated in residences, four levels of them can be distinguished. The first and lowest level includes open settlements without externally visible signs of fortifications, and without any evidence of bronze working. The second level includes hillforts with quite strong fortifications, but no bronze working has been found in them. In the lower reaches of the Daugava, these include the Sakaini and Daugmale hillforts. The third level corresponds to hillforts with strong fortifications, but the bronze working there took place only occasionally, and to a limited extent. The fourth and highest level includes well-fortified hillforts, where bronze processing played an important role in the lives of the inhabitants. In the lower reaches of the Daugava, the third level includes Vinnakalns, but the highest, the fourth level, includes Kivutkalns and Klangigukalns (Vasks 2007, p. 72). On the other hand, no signs of bronze processing have been found in the above-mentioned 12 rural open settlements in the lower reaches of the Daugava.

The nomenclature of bronze objects itself also provides an insight into the Bronze Age societies of the east Baltic. These are axes and spearheads, but swords are rare. These objects point to warfare as an elitist representation of society or a part of it, because, for example, due to their small size, some bronze axes were not suitable for real combat (just like the dagger in a modern army full dress uniform). Weapons made of stone, flint and bone were most likely used in real confrontations. Razors, cosmetic tweezers and tattoo needles were also made of bronze, which shows the concern of the users of these items about their appearance. Bronze tools are very rare. In the case of the lower reaches of the Daugava, these are the finds of two bronze sickles at Daugmale hillfort, and one fishing hook at Kivutkalns.

European Bronze Age societies have already been described as non-egalitarian, with a social hierarchy and an overlay: elites with their own dynasties, leaders, interconnections, centres of power, and new ideologies (Sherratt 1994). Several of the external features mentioned can also be seen in the Bronze and Earliest Iron Age archaeological material from Latvia, although in a weakened form, including the lower reaches of the Daugava. Bronze 


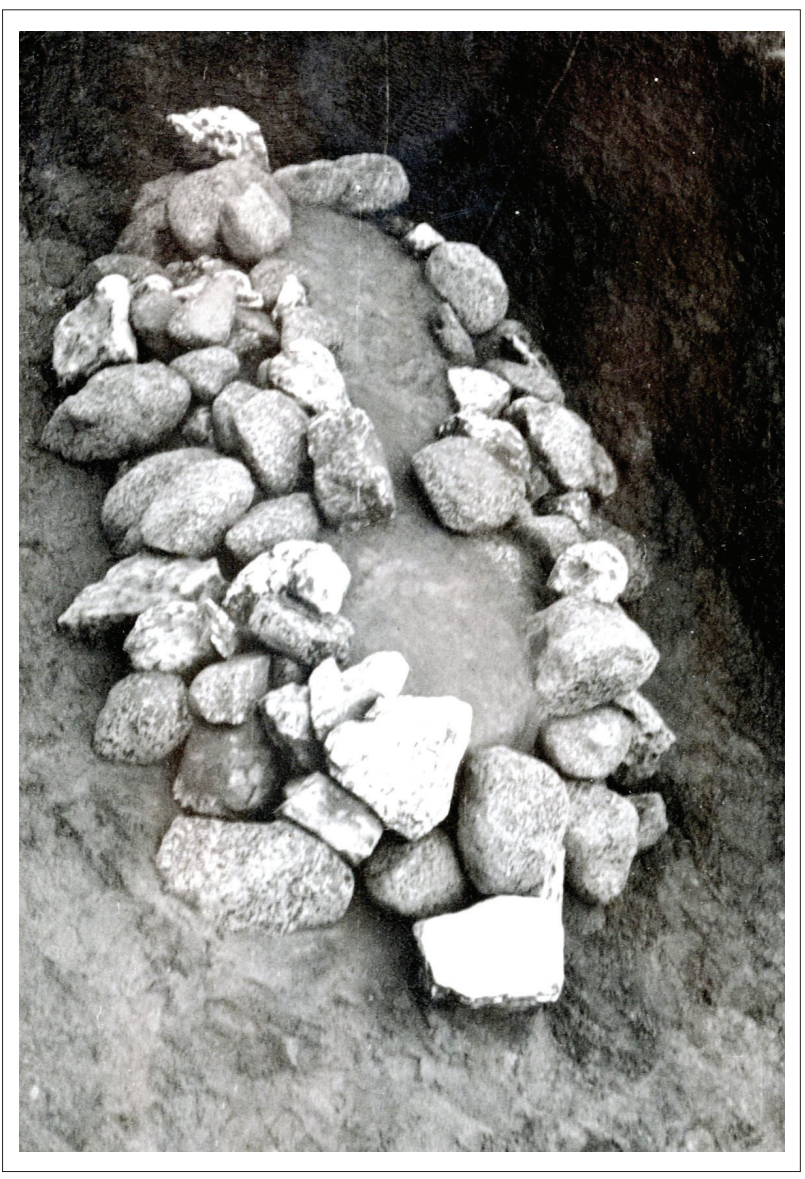

Figure 5. A 'leader's tomb'. The central stone cist of Rezne barrow 2, 7th century BC. Older burials were destroyed to bury this individual (photograph by Eduards Šturms, 1935, LNVM).

products point to aspects of social practice related to warfare and elite representation. The possibility of military conflict is also indicated by the construction of hillforts. On the other hand, these hillforts, and the bronze craftsmen working there, played an important role in regulating social relations. This gives us grounds to consider these bronze-treated hillforts, at least belonging to the highest, or fourth, level, also as centres for the maintenance of the social hierarchy. They can also be considered as centres of power, with their subordinate hillforts and open settlements. In general, in describing the processing of bronze and the specialisation of major centres in this sector, it should be acknowledged that it played an important role in strengthening the social position of the elite that controlled this sector, and the corresponding ideology. An important, if not the main role in the existence of these centres, was played by exchange relations with the southeast Baltic, and especially with Scandinavia, in connection with obtaining bronze. It is possible that we can already talk about the origins of the principles of trade, i.e., no longer the 'object for object' principle of exchange, characteristic of hunting-fishing-gathering groups, but about the 'property or goods of equivalent value, respectively money' market principle, characteristic of agricultural societies. This is suggested by the function of the abovementioned bronze armband-like rings as a possible commodity. In this respect, the Estonian archaeologist Valter Lang compares the contacts between the eastern and western shores of the Baltic Sea with Andrew Sherratt's model of the relationship between the centre, the periphery and the margin. Although Sherratt looks at the connections between southern, namely Mediterranean Europe, and northern Europe in the Bronze Age world system (Sherratt 1993), his model can also be used conceptually to describe contacts between different areas in northern and eastern Europe, including the east Baltic, with the centre in the west and the periphery in the east. Lang admits the possibility that scrap from bronze objects was transported from the west across the sea, as is shown by the Staldzene and Tehumardi hoards, so that the craftsmen of the east Baltic could melt them. Some of the bronze rings cast apparently remained with the local artisans, as a reward for their work (Lang 2007, pp. 117-119). The fact that fragments of casting moulds were found not only in the lower reaches of the Daugava, but in all the hillforts of the east Baltic where bronze processing was found, suggests the existence of a widely branched communication network between the western centre and the eastern periphery. In turn, these hillforts involved in bronze processing and long-distance exchange, according to Sherrat's model, could be centres in relation to the surrounding settlements as a periphery, where the bronze items made in the centre were exchanged for livestock, hunting and possibly agricultural products.

It is difficult to determine how large the controlled area of these metal-working hillforts could have been. In the better-studied Daugava area, one such area stands out in the lower reaches of the Daugava, from the Ogre estuary to the lower end of Dole Island, Lucavsala and Zaķusala. The main centre here was Kivutkalns on Dole Island, and to a lesser extent also Klangukalns and Vīnakalns. The other three downstream hillforts were probably dependent on both these centres, as were the open settlements in the area. The area could also have had its own sacred centre: Reznes barrow cemetery on the island in the Daugava. Such areas, whose societies are characterised by greater social complexity, also exist elsewhere in the east Baltic. In Lithuania, it was the coastal area and the northeastern part of the country; in Estonia, the island of Saaremaa, and the western and northern coasts; but in Latvia it was the southwest part and the Daugava coast, with the centre in the lower reaches of the Daugava. 


\section{Collapse}

Although the term is taken from medicine, which means sudden cardiovascular weakness, as well as an extreme state of physical weakness, such signs can be observed in the lower Daugava societies.

After the Bronze Age and in the Earliest Iron Age, with the very extensive use of natural resources in the lower reaches of the Daugava, the agricultural potential of the area diminished, and in the Earliest Iron Age a large part of the population moved to other places. Therefore, archaeological evidence of the continuation of settlement in the Earliest Iron Age to the beginning of the Viking Age (the 1st century to the 9th century $\mathrm{AD}$ ) is scarce: judging by a few cemeteries and stray finds, there were just a few points of settlement. However, the decisive factor in the decline of the area at the beginning of the Earliest Iron Age, when the demand for bronze as a prestigious material was declining against the growing demand for iron weapons, was apparently the loss of the former importance of the Daugava as an important transport artery. It is true that this waterway continued to be used in the Earliest Iron Age, as is indicated by the finds of Roman coins near the Daugava (Vasks 2001, Fig. 156), but it no longer had the former strategic importance for the societies of the lower Daugava. At the beginning of the Earliest Iron Age, east Baltic societies had acquired the skills to extract iron from bog/lake ore (Rundberger et al. 2020). Consequently, the earlier exchange relations, the main object of which was bronze, lost their significance, but the former advanced centres ceased to exist: in the lower reaches of the Daugava, they were Kivutkalns and Klangukalns, which in the 1 st or 2 nd centuries were abandoned. Although both these hillforts existed until the time when iron extraction in the east Baltic was already known, neither of them showed any signs of iron mining. The existence of such bronze processing and exchange centres apparently depended on the established social relations between those who maintained long-distance communication, bronze craftsmen and the local elite. The beginnings of iron mining were related to open settlements (for example, the Jaunlive settlement in the lower reaches of the Daugava, and the Spietini settlement above the Daugava). However, these were already societies that based their existence only on local resources, including the extraction and further processing of iron ore.

It is possible that the same can be said about Vinakalns, but for the time being, as long as there is a lack of ${ }^{14} \mathrm{C}$ analyses to find a more accurate chronology, the question remains open. At the same time, hillforts where bronzeworking activities did not play a major role in community life continued to exist. In the lower reaches of the Daugava, where the Daugmale hillfort is, life continued not only in the Early Iron Age, but also in the Migration period and the Viking Age (Zemitis 1996, pp. 217-221).

\section{Conclusions}

At the beginning of the Mesolithic, Neolithic and Bronze ages, the lower reaches of the Daugava were relatively sparsely populated. This can be explained by the priority given to the selection of areas more suitable for the fishinghunting-gathering economy (mainly the shores of lakes, and the rivers flowing into them). The situation began to change in the second half of the Early Bronze Age, in period III of the Bronze Age, when, starting from the 14th century $\mathrm{BC}$, new funeral traditions appeared by the Daugava, thus signaling the formation of a new society and the beginning of a new way of life. In the Early Bronze Age, judging by the settlements at Vampenieši and in the site of the later Daugmale hillfort, and by burial sites in Reznes and Vējstūri, as well as by stray finds of four stone hoes and axes, there were at least eight population points in the lower reaches of the Daugava. The sites of Vampenieši and Daugmale, as well as some other known Early Bronze Age settlements outside the lower Daugava area, are considered to be small farms with small populations. There is a lack of specific data on the livelihood strategy of the population during this period; however, taking into account the suitability of the lower Daugava for the development of animal husbandry and agriculture, it can be assumed that this is indicated indirectly by new burial traditions typical of livestock and farming communities: barrows with builtin stone cists and other structures, and the cremation of the dead. The different arrangement of the cemeteries at both Reznes and Kivutkalns indicates a different attitude towards the deceased, which apparently depended on their social status in society. This attitude stemmed from the ideology of the new society, in which the individual and his ability to stand out in his community (including in his appearance) played an important role.

Social differentiation in the Late Bronze Age is also indicated by the appearance of a new type of residence, fortified settlements or hillforts alongside earlier open settlements. Of the six hillforts downstream on the Daugava, Kivutkalns and Vīnakalns have been fully explored, and at Klangukalns only a significant part. The materials obtained show that the communities of these hillforts had already switched fully to animal husbandry and farming as the main branches of their livelihood strategy. Judging by the thick layers of fish remains at Kivutkalns, fishing in the Daugava was also important. Compared to the bones of livestock used for food, the small number of game bones indicates limited hunting opportunities on Dole Island, where forested areas decreased due to extensive farming. An important role for the communities of the lower 
reaches of the Daugava was their involvement in bronze processing and related exchange relations. Comparing the number of melting crucibles and mould fragments found to the amount of other artefacts, it can be seen how extensive bronze working was in the area. There are four levels. The first and lowest level includes rural open settlements, of which there are 12 in the lower reaches of the Daugava. The second includes hillforts, where, as in rural settlements, bronze processing has not been found. In our case, this is Daugmale hillfort. The third level includes Vinakalns, where bronze processing was episodic. The fourth and highest level includes Kivutkalns and Klangukalns, where this activity played an essential role in the economies of these communities. Judging by the moulds, bronze spearheads, axes and armband-like rings were cast. The range of bronze objects is dominated by weapons and ornaments; in addition, due to their small size, weapons, especially axes, had a symbolic, social representation rather than a practical meaning. Attention is drawn to the large number of fragments of moulds for casting armband-like rings (and in some cases, possibly also necklaces). Pieces of such moulds have been found not only in the lower reaches of the Daugava, but also in other hillforts from the time under consideration where bronze processing took place. These rings are considered to be ingots for storing and transporting metal, and in some cases also ornaments. It is possible that bronze rings also served as an exchange equivalent in the east Baltic, including the lower reaches of the Daugava, as the periphery of the overseas centre in Scandinavia. In turn, the bronze processing hillforts could have been centres in contact with the surrounding rural settlements, exchanging manufactured bronze objects for different types of products provided by the settlements.

With the beginning of the Earliest Iron Age and local iron metallurgy, the former socio-economic system based on bronze processing and exchange collapsed, and the largest centres of this system, at Kivutkalns, Klangukalns and presumably Vinakalns, ceased to exist. The next boom in the lower reaches of the Daugava followed only in the Viking Age, when the Daugava once again became one of the most strategically important highways between the west and the east.

\section{Acknowledgments}

This paper was prepared as a part of the research project 'Social Transformations in the Bronze Age Societies of the Lower Daugava River'(No Lzp-2018/2-0127), funded by the Latvian Council of Science. The author of the article is very grateful to the Latvian National Museum of History, and especially to Jānis Ciglis, the head of the Department of Archaeology, who kindly provided all the necessary in- formation about items from the Bronze Age and the Earliest Iron Age held in the department.

\section{References}

Atgāzis, M., 1972. Arheologisko pieminekḷu apzināšana Rīgas un Jelgavas rajonā. In: S. Levi, ed. Zinātniskās atskaites sesijas materiāli par arheologu, antropologu un etnogrāfu 1971. gada pētījumu rezultātiem. Rīga: Zinātne, pp. 44-47.

Ciglis, J., 2010. Mazjumpravas Gilbertu kapulauks un kausiņrotas Latvijā. Latvijas Zinātņu Akadēmijas Vēstis, Vol. 64, No 5/6, 55-65.

Ciglis, J., Vasks, A., 2017. Jauni bronzas un senākā dzelzs laikmeta apbedīšanas vietu datējumi ar radioaktīvā oglekḷa metodi. Latvijas Vēstures Institūta Žurnāls, 1, 35-61.

Denisova, R., Graudonis, J., Gravere, R., 1985. Kivutkalnskii mogil 'nik epokhi bronzy. Riga: Zinatne.

Girininkas, A., 2013. Lietuvos archeologija, II tomas: Ankstyvasis metalų laiokotarpis. Klaipeda: Klaipėdos Universiteto leidykla.

Graudonis, J., 1961. Reznu kapulauks. Arheologija un etnogrāfija, 3, 19-38.

Graudonis, J., 1967. Lavia $v$ epokhu pzdnei bronzi i rannego železa. Riga: Zinatne.

Graudonis, J., 1989. Nocietinātās apmetnes Daugavas lejtecēe. Rīga: Zinātne.

Graudonis, J., 1998. Intensīvas apdzīvotības sākums Daugavas lejtecè. In: A. Caune, ed. Senā Rìga. Pètījumi pilsētas arheoloǵijā un vēsturē. Rīga: Latvijas vēstures institūta apgāds, pp. 61-70.

Grikpèdis, M. and Motuzaitè-Matuzevišiūtè, G., 2018. A Review of the Earliest Evidence of Agriculture in Lithuania and the Earliest Direct AMS Data on Cereal. European Journal of Archaeology, 21 (2), 264-279.

Harding, A., 2000. European Societies in the Bronze Age. Cambridge World Archaeology. Cambridge University Press.

Krainov, D., 1972. Drevneishaia istoria Volgo - Okskogo mezhdurech `ia. Fatianovskaia kul 'tura. II tysiazheletie do n. e. Moskva: Nauka.

Krenke, N., 2019. Radiouglerodnaja hronologia fat ianovskoi kul turi. Rosiiskaia arheologia, 2, 110-116.

Kuz`minych, S., 1996. Osteuropäische und Fennoskandische tüllenbeile des Mälartyps: ein Rätsel der Archäologie. Fennoscandia archaeologica, 13, 3-27.

LA, 1974. Latvijas PSR arheoloǵija. Rīga: Zinātne.

Lang, V., 2007. The Bronze and Early Iron Ages in Estonia. Estonian Archaeology, 3. Tartu: University Press.

Lõugas, L., Kriiska, A., Maldre, L. 2007. New dates for the Late Neolithic Corded Ware Culture burials and early husbandry in the East Baltic region. Archaeofauna, 16, 21-31.

Loze, I., 1972. Stoianka Lagzha (Lubanskaia nizmennostj). Latvijas PSR Zinatnu akademijas vēstis, 6, 57-73.

Loze, I., 1979. Pozdnij neolit i ranniaia bronza Lubanskoi ravnini. Riga: Zinatne.

Loze, I., 1988. Poselenia kamennogo veka Lubanskoi nizini. Mezolit, rannij i srednij neolit. Riga: Zinatne.

Loze, I., 1997. Zemkopības ieviešana Latvijas teritorijā (Lubāna ezera baseins). Arheoloǵija un etnogrāfija, 19, 25-41.

Loze, I., 1998. Auklas keramikas kultūras savrupatradumi Rīgā un tās apkārtnē. In: A. Caune, ed. Senā Rīga. Pètījumi pilsētas arheologíijā un vēsturē. Rīga: Latvijas vēstures institūta apgāds, pp. 39-60.

Loze, I., 2001. Neolīts, 4500. - 1500. g. pr. Kr. In: J. Graudonis, J. Apals, eds. Latvijas senākā vēsture. 9. g. t. pr. Kr. - 1200. g. Rīga: Latvijas vēstures institūta apgāds, pp. 74-115. 
Oldeberg, A., 1974. Die Ältere metallzeit in Schweden, I. Stockholm: Kungl. Vitterhets Historie och Antikvitets Akademien

Podènas, V. and Čivilitė A., 2019. Bronze casting and communication in the southeastern Baltic Bronze Age. Lietuvos Archeologija, 45, 169-199.

Rimantienè, R., 2005. Die Steinzeit-fisher an der Ostseelagune in Litauen. Vilnius: Litauisches Nationalmuseum.

Ritums, R. and Kalniņa, L., 2002. Ieskats Abavas ielejas senāko apdzīvoto vietu izpētē. In: I. Virse ed. Latvijas arheoloǵija pètījumi un problēmas, Latvijas Vèstures muzeja raksti, Nr. 8. Rīga: Latvijas Vēstures muzejs, pp. 153-169.

Rundberger, B., Vasks, A., Gundersen, I., Brūzis, R., Larsen, J., Doniņa, I., Vīksna, A., 2020. Bloomery ironmaking in Latvia - a comparative study of Iron Age and medieval Technologies. Historical Metallurgy. The Journal of the Historical Metallurgy Society, 52 (2) for 2018, 96-108.

Sherratt, A., 1993. What would a Bronze-Age world system look like? Relations between temperate Europe and the Mediterranean in later prehistory, Journal of European Archaeology, 1 (2), 1-57.

Sherratt, A., 1994. The Emergence of Élites: Earlier Bronze Age Europe, 2500-1300 BC. In: B.W. Cunliffe, ed. The Oxford illustrated prehistory of Europe. Oxford, New York: Oxford University Press, pp. 244-276.

Stubavs, Ā., 1970. Arheologiskie izrakumi Salaspilī 1969. gadā. In: S. Levi, ed. Zinātniskās atskaites sesijas referätu tēzes par arheologu, antropologu un etnogrāfu 1969. gada pētījumu rezultātiem. Rīga: Zinātne, pp.59-63.

Stubavs, Ā., 1971. Arheologiskie izrakumi Salaspils pils vietā 1970. gadā. In: S. Levi, ed. Zinātniskās atskaites sesijas referātu tēzes par arheologu, antropologu un etnogrāfu 1971. gada pētījumu rezultātiem. Rīga: Zinātne, pp. 52-54.

Šturms, E., 1936 a. Akmens laikmeta atradumi Rīgā. Senatne un māksla, 3, 65-71.

Šturms, E., 1936 b. Latvijas akmens laikmeta materiāli, I. In: F. Balodis, K. Straubergs, ed. Latviešu aizvēstures materiāli, II. Rīga: Latviešu Filologu Biedrības izdevums, pp. 3-30.

Šnore, E., 1996. Daugavas lỉbieši Doles salā. Arheoloǵija un etnogräfija, 18.

Urtāns,V., 1977. Senākie depozìti Latvijā (lìdz 1200. g.). Rīga: Zinātne.

Vankina, L., 1962. Kaniešu pirmais kapulauks. In: Latvijas PSR Vēstures muzeja raksti. Arheologija, pp. 7-27.

Vankina, L., 1975. Pamiatniki kamenogo veka na teritorii Rigi i ee okrestnostei. In: Pamiatniki drevneishei istorii Evrazii. Moskva: Nauka, pp. 132-142

Vankina, L., 1980. Shnurovaia keramika na teritorii Latvii. In: Iz drevneishei istorii baltskikh narodov po dannim arkheologii $i$ antropologii. Riga: Zinatne, pp. 47-58.

Vasks, A., 1991. Keramika ephokhi poznei bronzi i rannego zheleza Latvii. Riga: Zinatne.

Vasks, A., 1994. Brikuḷu nocietinātā apmetne. Lubāna zemiene vèlajā bronzas un dzelzs laikmetā (1000. g. pr. Kr. -1000. g. pēc $K r$.). Rīga: Zinātne.

Vasks, A., 2001. Agrais dzelzs laikmets, 1. - 400. g. In: J. Graudonis, J. Apals, eds. Latvijas senākā vēsture. 9. g. t. pr. Kr. 1200. g. Rịga: Latvijas vēstures institūta apgāds, pp. 186-231.

Vasks, A., 2003. The symbolism of stone work-axes (based on material from the Daugava basin). Archaeologia Lithuana, 4, 27-32.

Vasks, A., 2005. Latvijas pilskalnu izpētes gaita. Latvijas Vēstures Institūta Žurnāls, 4, 9-45.

Vasks, A., 2007. Bronze-Working Centres in the System of Social Relations in the Territory of Latvia during the Early Metal Period. In: A. Merkevičius (ed). Colours of Archaeology. Material Culture and the Society. Papers from the Second Theoretical
Seminar of the Baltic Archaeologists (BASE) held at the University of Vilnius, October 21-22, 2005. Interarchaeologia, 2. Vilnius, Helsinki, Riga, Tartu, pp. 65-77.

Vasks, A., 2009. Burials on settlement sites: memories of ancestors or dissociation? In: A. Šnē, A. Vasks, eds. Memory, Society and Material Culture. Papers from the Third Theoretical Seminar of the Baltic Archaeologists (BASE) Held at the University of Latvia, October 5-6, 2007. Interarchaeologia, 3. Riga, Helsinki, Tartu, Vilnius, pp. 89-98.

Vasks, A., 2015. No medniekiem un zvejniekiem lìdz lopkopjiem un zemkopjiem. Latvijas aizvēstures senākais posms (10500. 1. g. pr. Kr.). Rīga: Zinātne.

Vasks, A., 2018. Kāstuve, deglis vai ogḷu trauks? Latvijas Vēstures Institūta Žurnāls, 1, 5-22.

Vasks, A., Vijups, A., 2004. Staldzenes bronzas laikmeta depozits. Staldzene Bronze Age Hoard. Rīga: Ventspils muzejs.

Vasks, A., Zarina, G., 2014. Kivutkalna pilskalns un kapulauks: jauni dati un jaunas problēmas. Latvijas Vēstures Institūta Žurnāls, 3, 5-36.

Vasks, A., Zarina, G., Legzdiṇa, D., Plankājs, E., 2021. New data on funeral customs and burials of the Bronze Age Reznes cemetery in Latvia. Estonian Journal of Archaeology, 25 (1), 3-31.

Wehlin, J., 2013. Östersjöns Skeppssättningar. Monument och mötesplaster under yngre bronsålder. Gotarc Series B. Gothenburg Archaeological Theses 59. Göteborgs Universitet.

Zagorska, I., 1998. Rīgas pilsētas un tās tuvākās apkaimes senākā apdzīvotỉba. In: A. Caune, ed. Senā Rīga. Pètījumi pilsētas arheologijāa un vēsturē. Rīga: Latvijas vēstures institūta apgāds, pp. 25-38.

Zagorska, I., 2012. Senie ziemeļbriežu mednieki Latvijā. Rīga: Zinātne,

Zariṇa, A., 1982. Celtniecība nocietinātā apmetnē Lielvārdes Dievukalnā. Latvijas Zinātņu Akadèmijas Vēstis, 7, 46-64.

Zarina, A., 1987. Salaspils Vējstūru kapulauki. Aheoloǵija un etnogräfija, 15, 19-44.

Zemītis, G., 1996. Daugmales pilskalna valnis. Arheologiija un etnogräfija, 18, 212-223.

Zvelebil, M., 2006. Mobility, contact, and exchange in the Baltic Sea basin 6000-2000 BC. Journal of Anthropological Archaeology, 25, 178-192.

\section{DAUGUVOS ŽEMUPYS \\ BRONZOS IR ANKSTYVUOJU \\ GELEŽIES AMŽIAIS \\ (1800-500-1 A.PR. KR.)}

\section{ANDREJS VASKS}

\section{Santrauka}

Mezolito pradžioje, neolite ir bronzos amžiuje Dauguvos žemupys buvo palyginti mažai apgyventas. Tai galima paaiškinti tuo, kad pirmenybe buvo teikiama teritorijoms, tinkamesnèms pasisavinamojo ūkio ekonomikai (daugiausia ežerų krantai ir upių i ežerą ịtekẻjimo vietos). Ši padètis pakito ankstyvojo bronzos amžiaus antrojoje pusėje, bronzos amžiaus III laikotarpiu, kai, pradedant nuo XIV a. pr. Kr., prie Dauguvos atsirado naujos laidojimo tradicijos, signalizuodamos apie naujos visuomenès 
susikūrimą ir pakitusio gyvenimo būdo pradžią. Ankstyvajame bronzos amžiuje, sprendžiant pagal Vampeniešių gyvenvietę ir vèlesnio Daugmalès piliakalnio vietą, pagal Reznes ir Vējstūrių kapinynus, taip pat pagal keturių akmeninių kaplių ir kirviu pavienius radinius, Dauguvos žemupyje buvo bent aštuoni gyvenamieji centrai (1 pav.). Vampeniešių ir Daugmalès gyvenvietès, taip pat kai kurios kitos žinomos ankstyvojo bronzos amžiaus gyvenvietès toliau nuo Dauguvos žemupio teritorijos laikomos mažais ūkiais, turinčiais nedideli gyventojų skaičių (2-4 pav.). Trūksta duomenų apie gyventojų pragyvenimo strategiją šiuo laikotarpiu, tačiau, atsižvelgiant ị Dauguvos žemupio tinkamumą gyvulininkystès ir žemès ūkio plètrai, galima manyti, kad netiesiogiai tai rodo naujos laidojimo tradicijos, būdingos gyvulininkystés ir ūkininkų bendruomenèms - pilkapiai su akmeninèmis ir kitomis konstrukcijomis, mirusiujų deginimas (5 pav.). Skirtingas kapinių išdèstymas tiek Reznes, tiek Ķivutkalnio gyvenvietėse rodo skirtingą požiūrị i mirusius asmenis, kas, matyt, priklausè nuo jų socialinès padèties visuomeneje. Šis požiūris kilo iš naujos visuomenès ideologijos, kurioje svarbus vaidmuo teko individui ir jo gebejjimui išsiskirti (taip pat ir pagal išvaizdą) savo bendruomenëje.

Vèlyvajame bronzos amžiuje socialinę diferenciaciją taip pat rodo naujo tipo gyvenamujuc vietų atsiradimas - įtvirtintos gyvenvietes ar piliakalniai šalia ankstesnių atvirojo tipo gyvenviečių. Iš šešių piliakalnių, esančių pasroviui nuo Dauguvos, Kivutkalnis ir Vīnakalnis buvo visiškai ištirti, o Klaṇgukalnio buvo ištirta gana nemaža dalis. Aptikta archeologinè medžiaga rodo, kad šių piliakalnių bendruomenès jau buvo visiškai perejjusios ị gyvulininkystę ir ūkininkavimą kaip pagrindinius pragyvenimo strategijos sektorius. Sprendžiant iš storų sluoksnių su žuvų kaulais Kivutkalnyje, žvejyba Dauguvoje taip pat buvo svarbi. Palyginti su naminių gyvulių kaulais, nedidelis medžiojamųjų žverrių kaulų skaičius rodo ribotas medžioklès galimybes Dolès saloje, kur miškų plotai dèl intensyvaus ūkininkavimo sumažėjo. Svarbus Dauguvos žemupio bendruomenių vaidmuo buvo jų dalyvavimas apdirbant bronzą ir su ja susiję mainų santykiai. Atsižvelgiant ị rastų tiglių ir liejimo formelių skaičių bei kitų artefaktų kiekio santykị, galima spręsti, koks platus bronzos apdorojimas buvo šioje srityje. Fiksuoti keturi lygiai. Pirmajam, žemiausiam, lygiui priskiriamos atvirojo tipo kaimo gyvenvietès, kurių Dauguvos žemupyje yra dvylika, o antrajam - piliakalniai, kur, kaip ir kaimo gyvenvietese, bronzos apdirbimo nefiksuota. Šiuo atveju tai Daugmalès piliakalnis. Trečiasis lygis apima Vinakalnị, kur bronzos apdirbimas buvo epizodinis. Ketvirtasis, aukščiausias, lygis apima Kivutkalnio ir Klaņgukalnio piliakalnius, kur ši veikla vaidino esmini vaidmenị šių bendruomenių ekonomikoje. Sprendžiant iš liejimo formų, buvo liejami bronziniai ietigaliai, kirviai ir apyrankès. Tarp bronzinių dirbinių tipų vyrauja ginklai ir papuošalai; ginklai, ypač kirviai, kurie dèl savo mažo dy- džio turèjo labiau simbolinę, socialinę, o ne praktinę reikšmę. Atkreipiame dèmesị ị daugybę liejimo formelių, skirtų apyrankems (kai kuriais atvejais galbūt ir karoliams). Tokių liejimo formų fragmentų aptikta ne tik Dauguvos žemupyje, bet ir kituose nagrinejamuose piliakalniuose, kur vyko bronzos apdirbimas. Šie žiedai laikomi luitais metalams laikyti ir gabenti, kai kuriais atvejais - ir kaip papuošalai. Gali būti, kad bronziniai žiedai taip pat buvo Rytų Baltijos, įskaitant Dauguvos žemupi, kaip periferijos, ryšys su užjūrio centru Skandinavijoje, mainų atitikmuo. Savo ruožtu piliakalniai, kuriuose būdavo apdirbamas metalas, galëjo būti centrai, kuriuose bendrauta su aplinkinemis kaimo gyvenvietemis, pagamintus bronzos daiktus iškeičiant $\mathfrak{i}$ ịvairių tipu gaminius, kuriuos teikè gyvenvietés. Teritorijų, panašių i d Dauguvos žemupị, kurių bendruomenėms būdingas didesnis socialinis kompleksiškumas, matoma ir kitose rytinès Baltijos regiono vietose. Lietuvos teritorijoje tokia buvo pajūrio zona ir šiaurès rytinè šalies dalis, Estijoje - Saremos sala, vakarinè ir šiaurinè pakrantès, o Latvijoje išsiskiria jos pietvakarinẻ dalis.

Prasidejus ankstyvajam geležies amžiui ir vietinei geležies metalurgijai, žlugo buvusi socialinè-ekonominè sistema, pagrista bronzos apdirbimu ir mainais, nustojo egzistuoti didžiausi šios sistemos centrai Ķivutkalnis, Klaņgukalnis ir, ko gero, Vīnakalnis. Kitas bendruomenių suklestejjimas Dauguvos žemupyje ịvyko vikingu laikais, kai Dauguva vèl tapo strategiškai viena svarbiausių kelių tarp Vakarų ir Rytų. 